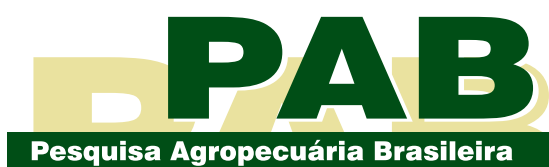

ISSN 1678-3921

Journal homepage: www.embrapa.br/pab

For manuscript submission and journal contents, access: www.scielo.br/pab

Wadson de Menezes Santos(1) (iD, Bruno José Rodrigues Alves(2) (D), Segundo Urquiaga ${ }^{(2)}(\mathrm{DD}$,

Edson Patto Pacheco(3) (D),

Inácio de Barros ${ }^{(4)}$ (iD,

Marcelo Ferreira Fernandes ${ }^{(3)}$ (iD),

Josimar Nogueira Batista(1) (iD),

Eduardo Pires Bender ${ }^{(5)}$ (D),

Heraldo Namorato de Souza(6) (iD) and

Claudia Pozzi Jantalia ${ }^{(2 \otimes)}$ (iD

(1) Universidade Federal Rural do Rio de Janeiro, Rodovia BR-465, Km 7, CEP 23890000 Seropédica, RJ, Brazil.

E-mail: wadson.wms@gmail.com

josimarbatista.agro@gmail.com

(2) Embrapa Agrobiologia, BR-465, $\mathrm{Km} 7$ Ecologia, CEP 23891-000 Seropédica, RJ, Brazil. E-mail: bruno.alves@embrapa.br, segundo.urquiaga@embrapa.br, claudia.jantalia@embrapa.br

(3) Embrapa Tabuleiros Costeiros, Avenida Beira Mar, no 3.250, Jardim, CEP 49025-040 Aracaju, SE, Brazil.

E-mail: edson.patto@embrapa.br marcelo.fernandes@embrapa.br

(4) Embrapa Gado de Leite, Rua Eugênio do Nascimento, no 610, Dom Bosco, CEP 36038 330 Juiz de Fora, MG, Brazil.

E-mail: inacio.barros@embrapa.br

(5) Universidade Federal de Sergipe, Avenida Marechal Rondon, s/no, Jardim Rosa Elze CEP 49100-000 São Cristóvão, SE, Brazil. E-mail: epiresbender@gmail.com

(6) Petrobrás, Cenpes, Avenida Horácio Macedo, № 950, Cidade Universitária da UFRJ, CEP 21941-915 Rio de Janeiro, RJ, Brazil. E-mail: heraldo.ns@petrobras.com.br

$\bowtie$ Corresponding author

Received

September 10, 2018

Accepted

May 5, 2020

How to cite

SANTOS, W. de M.; ALVES, B.J.R.; URQUIAGA S.; PACHECO, E.P..; BARROS, I. de; FERNANDES, M.F.; BATISTA, J.N.; BENDER, E.P.; SOUZA, H.N. de; JANTALIA, C.P. Ammonia volatilization and yield of corn fertilized with different nitrogen sources in the Brazilian semiarid. Pesquisa Agropecuária Brasileira, v.55, e01036, 2020. DOI: https://doi.org/10.1590/ S1678-3921.pab2020.v55.01036

\section{Ammonia volatilization and yield of corn fertilized with different nitrogen sources in the Brazilian semiarid}

\begin{abstract}
The objective of this work was to evaluate the effect of the use of different nitrogen fertilizers on $\mathrm{N}$ losses by $\mathrm{NH}_{3}$ volatilization and on the grain yield of a corn (Zea mays) crop grown in the semiarid region of the state of Sergipe, Brazil. Corn was managed under rainfed conditions and conventional tillage. The fertilization treatments were: sulfur-coated urea (SU) and organomineral-coated urea (OMU). Regular urea and ammonium sulfate (AS) were also included as a reference of $\mathrm{N}$ sources of high and low $\mathrm{NH}_{3}$-volatilization potential, as well as a control without $\mathrm{N}$ fertilization. The $\mathrm{N}$ sources were applied to the soil surface at a rate of $150 \mathrm{~kg} \mathrm{ha}^{-1} \mathrm{~N}$ as side-dressing at the V5 growth stage of corn. The experiment was carried out in 2015 and repeated in 2016. Losses of $\mathrm{N}$ through $\mathrm{NH}_{3}$ volatilization differed among the $\mathrm{N}$ sources in the two study years, with AS presenting the lowest $\mathrm{N}$ losses and regular urea, the highest. In the area treated with $\mathrm{OMU}$, losses by $\mathrm{NH}_{3}$ volatilization were consistently controlled, showing a reduction of 74 and $67 \%$ in relation to that of regular urea in both years. $\mathrm{SU}$, however, only mitigated $\mathrm{NH}_{3}-\mathrm{N}$ losses in 2015, increasing them in 2016, compared with regular urea. Corn plant grain yield and $\mathrm{N}$ status, assessed by the index leaf, did not clearly reflect $\mathrm{N}$ losses by $\mathrm{NH}_{3}$ volatilization. For the semiarid of Sergipe, OMU is the best ureabased fertilizer to mitigate $\mathrm{N}$ losses by $\mathrm{NH}_{3}$ volatilization, and the use of $\mathrm{AS}$ is an alternative to increase corn yield and eliminate $\mathrm{N}$ losses as $\mathrm{NH}_{3}$.
\end{abstract}

Index terms: Zea mays, ammonium sulfate, mitigation, urea-based fertilizers.

\section{Volatilização de amônia e produção de milho fertilizado com diferentes fontes de nitrogênio no semiárido brasileiro}

Resumo - O objetivo deste trabalho foi avaliar o efeito do uso de diferentes adubos nitrogenados nas perdas de $\mathrm{N}$ por volatilização de $\mathrm{NH}_{3}$ e no rendimento de grãos de cultura de milho (Zea mays) na região semiárida do estado de Sergipe. O milho foi manejado sob condições de sequeiro e preparo convencional. Os tratamentos de fertilização foram: ureia revestida com enxofre (SU) e ureia organomineral (OMU). Também foram incluídos ureia comercial e sulfato de amônio (SA) como referência de fontes de $\mathrm{N}$ com alto e baixo potencial de volatilização de $\mathrm{NH}_{3}$, além de um controle não fertilizado com $\mathrm{N}$. As fontes de $\mathrm{N}$ foram aplicadas na superfície do solo a uma taxa de $150 \mathrm{~kg} \mathrm{ha}^{-1}$ de N, como cobertura, no estádio V5 de crescimento do milho. O experimento foi realizado em 2015 e repetido em 2016. As perdas de $\mathrm{N}$ pela volatilização de $\mathrm{NH}_{3}$ foram diferentes entre as fontes de $\mathrm{N}$ nos dois anos de estudo, com SA tendo apresentado a menor perda de $\mathrm{N}$ e ureia comercial, a maior. $\mathrm{Na}$ área tratada com $\mathrm{OMU}$, as perdas pela volatilização de $\mathrm{NH}_{3}$ foram controladas de forma consistente, tendo mostrado redução de 74 e $67 \%$ em relação à da ureia regular em ambos os anos. SU, no entanto, apenas mitigou as perdas de $\mathrm{NH}_{3}$ em 2015, tendo as aumentado em 2016, em comparação à ureia comercial. O rendimento de grãos e o status de $\mathrm{N}$ da planta de milho, 
avaliados pela folha-índice, não refletiram claramente a perda de $\mathrm{N}$ pela volatilização de $\mathrm{NH}_{3}$. Para o semiárido de Sergipe, OMU é o melhor fertilizante à base de ureia para mitigar as perdas de $\mathrm{N}$ pela volatilização de $\mathrm{NH}_{3}$, e o uso de SA é uma alternativa para aumentar o rendimento do milho e eliminar as perdas de $\mathrm{N}$ como $\mathrm{NH}_{3}$.

Termos para indexação: Zea mays, sulfato de amônio, mitigação, fertilizantes à base de ureia.

\section{Introduction}

For most Brazilian soils, the natural availability of nitrogen to the plants is low, making $\mathrm{N}$ fertilization a countrywide strategy for improving crop yield (Cancellier et al., 2016). At present, almost 4.4 million tons of $\mathrm{N}$ are applied to cropped soils, mainly to those with corn and sugarcane (Heffer \& Prud'homme, 2016). Worldwide, urea is the main agricultural $\mathrm{N}$ source used, corresponding to $48 \%$ of the 107 million tons of $\mathrm{N}$ fertilizer applied in 2017 (IFA, 2019). In Brazil, urea has also been widely used, representing about $50 \%$ of the total $\mathrm{N}$ applied in agriculture in the last two to three decades, which is likely related to its high $\mathrm{N}$ concentration $( \pm 45 \%)$, allowing reductions in transport and application costs (Alves at al., 2016).

In general, $\mathrm{N}$ fertilization is split in two or more doses: part applied to the seedbed and the remainder by broadcasting or side-dressing. For the corn crop in Brazil, seedbed fertilization is followed by the application of urea, after 25 to 30 days of plant emergence, as the main $\mathrm{N}$ source, at rates varying from 80 to $160 \mathrm{~kg} \mathrm{ha}^{-1}$, depending on yield expectation and cropping system management (Coelho et al., 2008). However, urea hydrolysis into $\mathrm{NH}_{4}^{+}$and $\mathrm{CO}_{2}$ results in an increase of up to 8-9 in soil $\mathrm{pH}$ around the fertilizer granule and in the shift of $\mathrm{NH}_{4}{ }^{+}$ions to the volatile $\mathrm{NH}_{3}$ form (Sommer et al., 2004).

The global estimate of ammonia volatilization from soil fertilized with urea ranges from 10 to $20 \%$, but can be much greater in the warmer regions of the tropics (Cantarella et al., 2018). Measurements performed in sugarcane areas during the warm and wet Brazilian summer showed 1 to $25 \% \mathrm{NH}_{3}-\mathrm{N}$ losses when 80 to $100 \mathrm{~kg} \mathrm{ha}^{-1} \mathrm{~N}$ urea were broadcast on the trash blanket; these were the lowest losses associated with the occurrence of rainfall at the date of $\mathrm{N}$ fertilization (Cantarella et al., 2008). However, Lara Cabezas et al. (2000) also reported $\mathrm{NH}_{3}-\mathrm{N}$ losses with the application of 40 and $78 \%$ urea to a corn crop under conventional soil preparation and no-tillage, respectively.

The economic importance of urea as a $\mathrm{N}$ source for the Brazilian cropping systems has motivated studies to test enhanced urea fertilizers devised to reduce $\mathrm{NH}_{3}$ volatilization rates. The use of $\mathrm{N}$-(n-butyl) thiophosphoric triamide (NBPT) as an urease inhibitor has been shown to reduce $\mathrm{NH}_{3}$ losses by $53 \%$; however, its use is constrained by its limited effect on crop yield and its high prices (Cantarella et al., 2018). Coating urea with polymers mixed or not with cooper, boron, or sulfur has also been investigated. While polymers would help retarding urea release, the presence of $\mathrm{Cu}$, $\mathrm{B}$, and $\mathrm{S}$ would have competitive and non-competitive effects on urease activity, with a variable impact on losses by volatilization and reduced effects on crop yield (Cancellier et al., 2016).

Therefore, significant reductions in $\mathrm{NH}_{3}$ losses are not converted into proportional yield gains, which is still not clear why. Probable causes for this include crop cycle and soil N reserves (Cantarella et al., 2018). In addition, the confounding effects due to fertilization time and rainfall occurrence increase the variability of existing data, which limits a definitive conclusion on the advantages of enhanced fertilizers. The scarce information on these products for some regions of Brazil, such as the semiarid, is another constraint for broader recommendations (Cantarella \& Montezano, 2010).

The objective of this work was to evaluate the effect of the use of different $\mathrm{N}$ fertilizers on $\mathrm{N}$ losses by $\mathrm{NH}_{3}$ volatilization and on the grain yield of a corn crop grown in the semiarid region of the state of Sergipe, Brazil.

\section{Materials and Methods}

The experiment was conducted during the 2015 and 2016 crop seasons in an area cropped with corn (Zea mays L.) under conventional tillage for several years, located at the experimental station of Embrapa Tabuleiros Costeiros, in the state of Sergipe, Brazil $\left(10^{\circ} 27^{\prime} \mathrm{S}, 37^{\circ} 11^{\prime} \mathrm{W}\right.$, at $200 \mathrm{~m}$ above sea level). By the Brazilian soil classification system, the soil is an Argissolo Vermelho-Amarelo distrófico (Santos et al., 2013), i.e., a Haplic Acrisol (FAO, 2015). According to Köppen's classification, the climate is of the AS type, being characterized as rainy tropical with a 
dry summer. From 2001-2016, the mean annual temperature was $26^{\circ} \mathrm{C}$ and annual precipitation was $1,051 \mathrm{~mm}$, of which $68 \%$ occurred between May and October (Figure 1).

The area was limed in 2014 at a rate of $1.2 \mathrm{Mg} \mathrm{ha}^{-1}$ incorporated to a $20-\mathrm{cm}$ depth. Soil samples were taken from the $0-20$ and $20-40-\mathrm{cm}$ layers two months before the experiment was installed for chemical and physical characterization (Table 1) using the methods described in Silva (1999). Prior to sowing, the area was ploughed and harrowed twice. Corn was mechanically sowed without $\mathrm{N}$ fertilizer application on $05 / 20 / 2015$ and $05 / 16 / 2016$ at a row spacing of $0.50 \mathrm{~m}$, totalizing 74,000 plants per hectare. The single-cross corn hybrid, AG 7088 VT PRO Max (Agroceres, Rio Claro, SP, Brazil), was used in both years. Fertilization with $\mathrm{P}$ and $\mathrm{K}$ was carried out at sowing, by applying $100 \mathrm{~kg}$

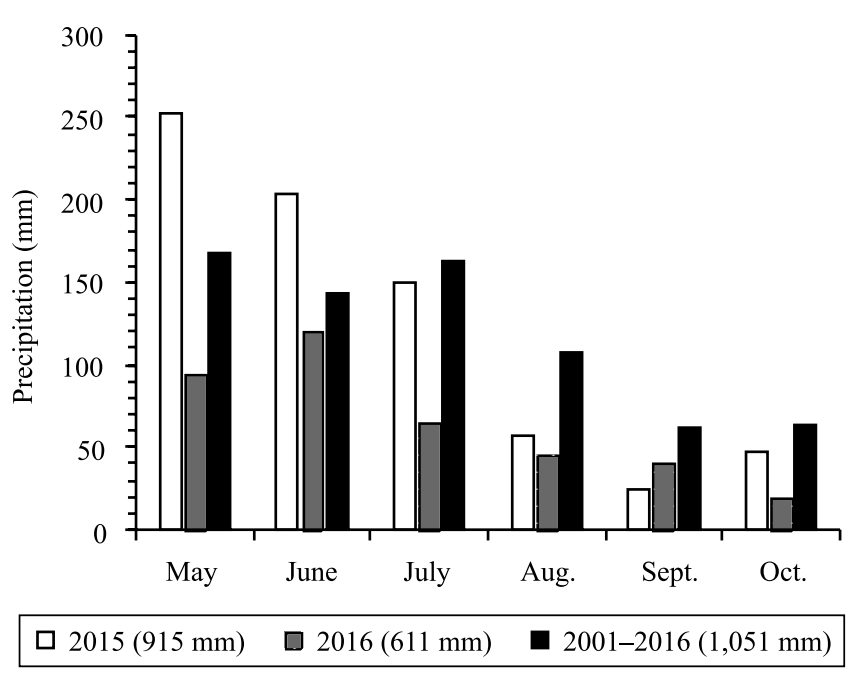

Figure 1. Monthly precipitation during the corn (Zea mays) vegetative cycle in 2015 and 2016, and average monthly precipitation in the period from 2001-2016. ha $^{-1} \mathrm{P}_{2} \mathrm{O}_{5}$ as triple superphosphate and $80 \mathrm{~kg} \mathrm{ha}^{-1} \mathrm{~K}_{2} \mathrm{O}$ as potassium chloride, due to the low $\mathrm{P}\left(<7 \mathrm{mg} \mathrm{dm}^{-3}\right)$ and medium K (30 to $45 \mathrm{mg} \mathrm{dm}^{-3}$ ) availabilities, both considered limiting for high grain yield (Sobral et al., 2007).

The $\mathrm{N}$ fertilization treatments consisted of: sulfurcoated urea (SU), containing $37 \% \mathrm{~N}$ and $16 \% \mathrm{~S}(\mathrm{FH}$ Nitro Gold, Fertilizantes Heringer, Rosário do Catete, SE, Brazil); and organo-mineral-coated urea (OMU), containing $29 \% \mathrm{~N}, 9 \% \mathrm{~S}, 5 \% \mathrm{Ca}, 2 \% \mathrm{Mg}$, and $0.3 \%$ B (Sulfammo MeTA, TIMAC Agro, Santa Luzia do Norte, AL, Brazil). Dry granular urea with $46 \% \mathrm{~N}$ (Petrobras, Fafen-SE, Laranjeiras, SE, Brazil) and ammonium sulfate (AS) with $20 \% \mathrm{~N}$ and $22 \% \mathrm{~S}$ (Petrobras, Fafen-SE, Laranjeiras, SE, Brazil) were also included as a reference of regular $\mathrm{N}$ sources, as well as a control without $\mathrm{N}$ fertilization. The experiments were arranged in a randomized complete block design, with five treatments and three replicates. The experimental units were $2 \times 5-\mathrm{m}$ plots with four plant rows. To prevent a bordering effect, only the two central rows in the plot, discarding $0.5 \mathrm{~m}$ from both ends of each row, were sampled. The $\mathrm{N}$ fertilizers were surface applied to the total area between rows at a rate of $150 \mathrm{~kg} \mathrm{ha}^{-1} \mathrm{~N}$, at 36 and 31 days after sowing in 2015 and 2016, respectively, during the V5 growth stage of corn, when plants have a high demand for N (Sangoi et al., 2007). Even though the application of the whole $\mathrm{N}$ dose as side-dressing is unusual, its potential for use in treatments is likely improved as $\mathrm{NH}_{3}$ losses by volatilization are expected to increase with urea- $\mathrm{N}$ rates (Cantarella et al., 2018).

Immediately after $\mathrm{N}$ fertilization, two semi-open chambers (Araújo et al., 2009; Jantalia et al., 2012) per plot were installed to measure $\mathrm{NH}_{3}$ volatilization: one in a row between plants and another in the interrow space. The chamber was made of a transparent polyethylene terephthalate (PET) bottle, with a $2.0-\mathrm{L}$

Table 1. Soil chemical and physical characteristics in the experimental area.

\begin{tabular}{|c|c|c|c|c|c|c|c|c|c|c|c|c|c|}
\hline \multirow[t]{3}{*}{ Depth } & \multicolumn{10}{|c|}{ Chemical characteristics } & \multicolumn{3}{|c|}{ Physical characteristics } \\
\hline & \multirow{2}{*}{$\underset{\left(\mathrm{H}_{2} \mathrm{O}\right)}{\mathrm{pH}}$} & \multirow{2}{*}{$\begin{array}{c}\mathrm{OM}^{(1)} \\
\left(\mathrm{g} \mathrm{kg}^{-1}\right)\end{array}$} & $\mathrm{P}$ & $\mathrm{K}$ & $\mathrm{Ca}$ & $\mathrm{Mg}$ & $\mathrm{H}+\mathrm{Al}$ & $\mathrm{Al}$ & $\mathrm{Na}$ & \multirow{2}{*}{$\begin{array}{l}\mathrm{V}^{(2)} \\
(\%)\end{array}$} & Sand & Silt & Clay \\
\hline & & & \multicolumn{2}{|c|}{$\left.(\mathrm{mg} \mathrm{dm})^{-3}\right)$} & ------- & ------ & $\operatorname{mol}_{\mathrm{c}} \mathrm{dn}$ & - & - & & \multicolumn{3}{|c|}{------- $\left(\mathrm{g} \mathrm{kg}^{-1}\right)$----- } \\
\hline $0-20 \mathrm{~cm}$ & 5.9 & 16.3 & 6.2 & 35.9 & 24.2 & 18.8 & 11.9 & 0.3 & 1.3 & 79.2 & 552 & 183 & 265 \\
\hline $20-40 \mathrm{~cm}$ & 5.8 & 12.9 & 2.4 & 16.8 & 21.9 & 16.6 & 12.0 & 0.2 & 0.9 & 76.8 & 489 & 194 & 317 \\
\hline
\end{tabular}

${ }^{(1)} \mathrm{OM}$, organic matter. ${ }^{(2)} \mathrm{V}$, base saturation. 
capacity and $100-\mathrm{mm}$ diameter $\left(78.5 \mathrm{~cm}^{2}\right)$, whose bottom was removed, leaving it with a final length of $260 \mathrm{~mm}$. Inside each chamber, a $25-\mathrm{cm}$ long wire was used to support a $2.5 \times 25-\mathrm{cm}$ foam strip with $3.0 \mathrm{~mm}$ of thickness and also a $50-\mathrm{mL}$ plastic pot, placed at the bottom end. Before chamber deployment, the foam strip was pre-soaked in a $10-\mathrm{mL}$ acid solution of $1.0 \mathrm{~mol} \mathrm{~L}^{-1}$ sulfuric acid $+2.0 \%$ glycerol. After that, the upper side of the foam was hung on top of the wire support and the other extremity was put inside the plastic pot held by the wire; the solution that was not absorbed by the foam remained inside the pot. The foam was replaced daily every five days depending on the sampling scheme defined for each year of the study. According to Araújo et al. (2009), foam is efficient for trapping volatilized $\mathrm{NH}_{3}$ for periods of up to six days.

To ensure the homogeneity of fertilizer application, a $0.9-\mathrm{m}$ space in the plant rows was reserved to manually receive a corresponding amount of fertilizer, whose granules were carefully spread out. This area was used to monitor $\mathrm{NH}_{3}$ volatilization time. When the foam was replaced, the chamber was reallocated to the next position in the reserved area based on the procedure described by Jantalia et al. (2012). This reallocation aimed to expose the fertilized area to rainfall, dewing, and evaporation (Cantarella et al., 2008). Foams and their respective plastic pots were replaced on a daily basis during the first 7 days after $\mathrm{N}$ fertilization (DAF) in both study years and on the ninth, thirteenth, and eighteenth DAF in 2015, and on the eighth, tenth, and thirteenth DAF in 2016. Still in the field, the replaced foam strips were immediately put in their corresponding plastic pot and sent to a laboratory for the $\mathrm{NH}_{3}-\mathrm{N}$ analysis. There, ammonia- $\mathrm{N}$ was determined after a careful transfer of the foam to an Erlenmeyer flask, followed by rinsing the plastic pots with $50 \mathrm{~mL}$ deionized water. The procedure of $\mathrm{NH}_{4}{ }^{+}$quantification in the solution was detailed in Araújo et al. (2009). A correction factor was developed by Araújo et al. (2009) and Jantalia et al. (2012) using the ${ }^{15} \mathrm{~N}$ balance as a measure of the real $\mathrm{NH}_{3}$ volatilization. The cumulative $\mathrm{NH}_{3}-\mathrm{N}$ volatilization for the whole deployment period was calculated by summing up the results obtained for each intermediary sample. The fraction of the $\mathrm{N}$ fertilizer lost as $\mathrm{NH}_{3}$ $\left(\mathrm{Frac}_{\mathrm{GASF}}\right)$ was calculated as the ratio of the net $\mathrm{NH}_{3}-\mathrm{N}$ volatilized and the $\mathrm{N}$ fertilizer rate, all in a same area basis (Eggleston et al., 2006). The net $\mathrm{NH}_{3}-\mathrm{N}$ volatilized was calculated as the difference between the cumulative $\mathrm{NH}_{3}-\mathrm{N}$ obtained for the $\mathrm{N}$ source and the control.

In the experiment carried out in 2015, five plants at the R1 growth stage were randomly chosen from each plot. The opposite leaf immediately below the first ear - index leaf for $\mathrm{N}$ fertility - was collected and processed for further analysis of $\mathrm{N}$ content (\%) using Kjeldahl digestion (Silva, 1999). To determine grain yield, whole corn plants from a $1.5-\mathrm{m}^{2}$ area of each plot were manually harvested in late October each year - on the $29^{\text {th }}$ in 2015 and on the $17^{\text {th }}$ in 2016 -, when the plants were at or near physiological maturity. For mass determination, the grains were separated from the ears with a mechanical sheller, and yield was expressed on a $130-\mathrm{g} \mathrm{kg}^{-1}$ moisture content basis.

The data of cumulative $\mathrm{NH}_{3}$ volatilization and grain yield were subjected to the analysis of variance (Anova), and means were compared using Fisher's least significant difference test, at $5 \%$ probability. The Anova was carried out after checking for normality of errors by Shapiro-Wilk's normality test and for homoscedasticity by Levene's test. Data were log (x) transformed when the assumptions for the Anova were not meet. Pearson's correlation was performed between volatilized $\mathrm{NH}_{3}$ and the $\mathrm{N}$ content of the index leaf. Statistical analyses were performed using the Sisvar, version 5.6 (Ferreira, 2011), and the XLSTAT, version 2020.1.1, software (Addinsoft, Paris, France).

\section{Results and Discussion}

For both study years, $\mathrm{NH}_{3}$ volatilization due to the treatments remained for no longer than $10 \mathrm{DAF}$, indicating that the monitoring time of 13 and 18 days was enough to compute the whole $\mathrm{N}$ loss, regardless of fertilizer type (Figure 2). The urea-based fertilizers regular urea, $\mathrm{OMU}$, and $\mathrm{SU}-$ had $\mathrm{NH}_{3}$ volatilization rates well above those of the control, while AS was virtually inert to this $\mathrm{N}$-loss process. The process of $\mathrm{NH}_{3}$ volatilization is primarily dependent on the dissociation of $\mathrm{NH}_{4}^{+}$into $\mathrm{NH}_{3}$ and $\mathrm{H}^{+}$, whose magnitude will vary with $\mathrm{NH}_{4}{ }^{+}$and $\mathrm{H}^{+}$availabilities in the soil. For instance, the application of AS increases the concentration of $\mathrm{NH}_{4}{ }^{+}$but contributes to soil acidification (Zhao et al., 2007). Therefore, $\mathrm{NH}_{3}$ volatilization from this source is frequently very low when on neutral to acid soils

Pesq. agropec. bras., Brasília, v.55, e01036, 2020

DOI: 10.1590/S1678-3921.pab2020.v55.01036 

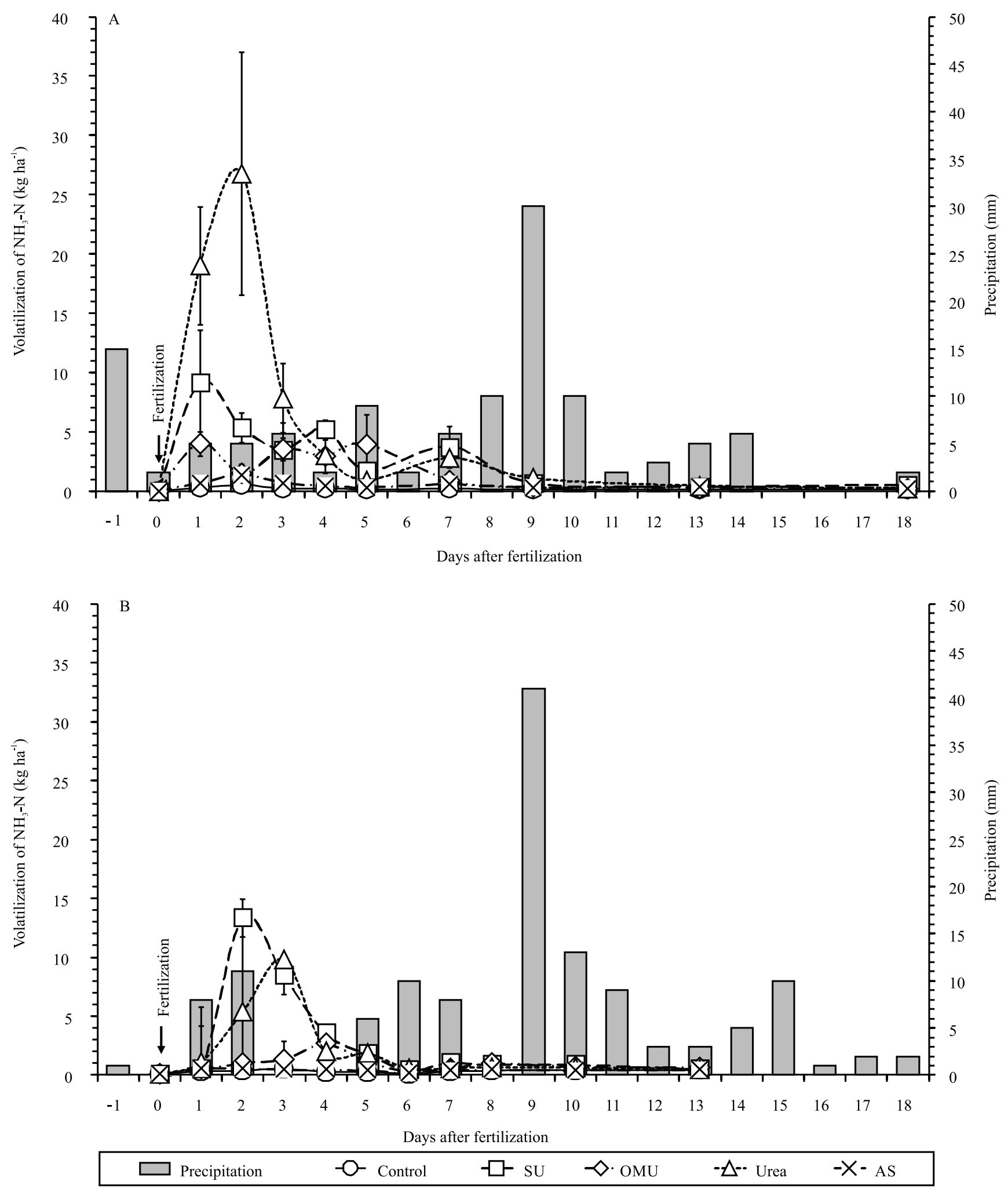

Figure 2. Daily flux of ammonia volatilization and precipitation up to the eighteenth day after the application of $150 \mathrm{~kg} \mathrm{ha}^{-1}$ $\mathrm{N}$ in the 2015 (A) and 2016 (B) corn (Zea mays) crop seasons. Bars indicate the default error. Control, without $\mathrm{N}$ fertilization; $\mathrm{SU}$, sulfur-coated urea; OMU, organo-mineral-coated urea; Urea, granular urea; and AS, ammonium sulfate. 
(Chien et al., 2011). This justifies the similar $\mathrm{N}$ losses in the AS and control treatments for both experimental years; AS only caused losses 0.9 to $3.1 \mathrm{~kg} \mathrm{ha}^{-1} \mathrm{~N}$ above those of the control, representing less than $2.5 \%$ of the $\mathrm{N}$ applied (Table 2). In contrast, the alkaline reaction of urea removes $\mathrm{H}^{+}$from the soil solution and enhances the dissociation of $\mathrm{NH}_{4}^{+}$that may lead to significant $\mathrm{N}$ losses through $\mathrm{NH}_{3}$ volatilization (Sommer et al., 2004).

In 2015, all the urea-based treatments presented $\mathrm{NH}_{3}$ losses higher than those of the control until 7 DAF, which corresponded to $95.4 \%$ of the total $\mathrm{NH}_{3}-\mathrm{N}$ loss. Lower volatilization rates were registered in 2016, with maximum volatilizations rates of 14 and $10 \mathrm{~kg} \mathrm{ha}^{-1}$, respectively, at $2 \mathrm{DAF}$ in areas treated with $\mathrm{SU}$ and at $3 \mathrm{DAF}$ with urea. After $6 \mathrm{DAF}, \mathrm{NH}_{3}$ volatilization decreased to the basal levels measured in the non-fertilized control (Figure 2 B). Very often, $\mathrm{NH}_{3}$ losses from urea are very intense within the first three days after the process starts, and most of the $\mathrm{N}$ loss is computed in no more than a week (Sommer et al., 2004; Cantarella et al., 2018). However, in the present study, fertilizers showed different patterns and magnitudes of $\mathrm{NH}_{3}$ volatilization. In 2015, $\mathrm{NH}_{3}$ volatilization increased very fast for the urea-based fertilizers, but following slightly different patterns (Figure $2 \mathrm{~A}$ ). For the $\mathrm{SU}$ and $\mathrm{OMU}$ treatments, $\mathrm{NH}_{3}$ volatilization peaked at $1 \mathrm{DAF}$, with a $\mathrm{N}$ loss of 9 and $4 \mathrm{~kg} \mathrm{ha}^{-1}$, respectively, while the regular urea treatment had a volatilization peak at $2 \mathrm{DAF}$, with a $27-\mathrm{kg} \mathrm{ha}^{-1}$ $\mathrm{NH}_{3}-\mathrm{N}$ loss. The volatilization rates tended to reduce, but in an oscillating manner, which was relatively more relevant for SU and OMU. This pattern was considered as a result of the gradual liberation of urea across the coating layer (Mariano et al., 2019). In 2016, this behavior was not observed, but there was a 1-day delay for the highest losses, together with an inversion in the

Table 2. Cumulative $\mathrm{NH}_{3}-\mathrm{N}$ and $\mathrm{N}$-fertilizer losses, emission factor, and reduction of losses by volatilization of fertilizers in relation to urea when applying $150 \mathrm{~kg} \mathrm{ha}^{-1} \mathrm{~N}$ to corn (Zea mays) in the 2015 and 2016 crop seasons ${ }^{(1)}$.

\begin{tabular}{|c|c|c|c|c|c|}
\hline \multirow[t]{2}{*}{ Treatment $^{(2)}$} & \multicolumn{2}{|c|}{$\mathrm{NH}_{3}-\mathrm{N}$ losses $\left(\mathrm{kg} \mathrm{ha}^{-1}\right)$} & \multirow{2}{*}{$\begin{array}{c}\text { Total } N \text { applied } \\
(\%)\end{array}$} & \multirow{2}{*}{$\begin{array}{l}\text { Fraction of applied } \\
\mathrm{N} \text { lost as } \mathrm{NH}_{3}-\mathrm{N}\end{array}$} & \multirow{2}{*}{$\begin{array}{l}\text { Reduction compared } \\
\text { with urea }(\%)\end{array}$} \\
\hline & Cumulative $\mathrm{NH}_{3}-\mathrm{N}$ & $\mathrm{NH}_{3}-\mathrm{N}$ fertilizer & & & \\
\hline & & & 2015 experiment & & \\
\hline OMU & $17.2 \mathrm{~b}$ & $15.6 \mathrm{bc}$ & 10.4 & 0.10 & 74.1 \\
\hline SU & $30.2 \mathrm{ab}$ & $28.3 \mathrm{ab}$ & 18.9 & 0.19 & 53.0 \\
\hline AS & $5.0 \mathrm{c}$ & $3.1 \mathrm{c}$ & 2.1 & 0.02 & 94.9 \\
\hline Urea & $62.1 \mathrm{a}$ & $60.2 \mathrm{a}$ & 40.1 & 0.40 & - \\
\hline Control & $1.9 \mathrm{c}$ & - & - & - & - \\
\hline Mean & 23.3 & 26.8 & 17.9 & 0.18 & - \\
\hline \multirow[t]{2}{*}{ Coefficient of variation $(\%)$} & 22.95 & 33.27 & - & - & - \\
\hline & & & 2016 experiment & & \\
\hline OMU & $9.3 b c$ & $6.4 \mathrm{~b}$ & 4.3 & 0.04 & 67.2 \\
\hline SU & $31.1 \mathrm{a}$ & $28.3 \mathrm{a}$ & 18.9 & 0.19 & -45.1 \\
\hline AS & $3.8 \mathrm{~cd}$ & $0.9 \mathrm{c}$ & 0.6 & 0.01 & 95.4 \\
\hline Urea & $22.3 \mathrm{ab}$ & $19.5 \mathrm{ab}$ & 13.0 & 0.13 & - \\
\hline Control & $2.8 \mathrm{~d}$ & - & - & - & - \\
\hline Mean & 13.9 & 13.8 & 9.2 & 0.9 & - \\
\hline Coefficient of variation (\%) & 22.41 & 37.05 & - & - & - \\
\hline
\end{tabular}

${ }^{(1)}$ Means followed by equal letters do not differ statistically by Fisher's least significant difference test, at 5\% probability. ${ }^{(2)}$ OMU, organo-mineral-coated urea; SU, sulfur-coated urea; AS, ammonium sulfate; Urea, granular urea; and Control, without N fertilization. 
importance of urea with SU in terms of the magnitude of the losses.

According to Sommer et al. (2004), the triggering of $\mathrm{NH}_{3}$ volatilization after urea placement on the soil will depend on urea dissolution and hydrolysis into $\mathrm{NH}_{4}{ }^{+}$ and $\mathrm{HCO}_{3}{ }^{-}$. The latter produces a $\mathrm{H}^{+}$sink around the urea granule and enhances the dissociation of $\mathrm{NH}_{4}^{+}$. Soil temperature and moisture are key factors in the dissolution and hydrolysis of urea (Da Ros et al., 2005) and are likely to control the extension of the lag phase between urea application to the soil and the start of $\mathrm{NH}_{3}$ volatilization.

In 2015, soil moisture was probably high due to the $12-\mathrm{mm}$ rainfall the day before fertilizer application, contrarily to the observed in 2016, when rainfall was very low both on this day and throughout the year (Figure 2). This difference is the probable explanation for the shorter lag phase between fertilization and $\mathrm{NH}_{3}$ volatilization in 2015. However, rainfall during the first days after fertilization was almost twice as great in 2016 and increased the chances of moving the dissolved urea into the soil, causing a reduction in $\mathrm{NH}_{3}$ volatilization. Similar effects were reported by Black et al. (1987) in a study under controlled conditions. In 2015 and 2016, the use of regular urea resulted in 62.1 and $22.3 \mathrm{~kg} \mathrm{ha}^{-1} \mathrm{~N}$ lost as $\mathrm{NH}_{3}$ or in a net loss of 60.2 and $19.5 \mathrm{~kg} \mathrm{ha}^{-1} \mathrm{NH}_{3}-\mathrm{N}$ if the $\mathrm{NH}_{3}$ volatilization computed for the control is deduced (Table 2).

Consistently, the use of OMU, a urea-based product, caused a lower $\mathrm{NH}_{3}$ volatilization in both years (Figure 2), amounting net losses of 15.6 and 6.4 $\mathrm{kg} \mathrm{ha}^{-1}$ in 2015 and 2016, respectively, representing 10.4 and $4.3 \%$ of the added $\mathrm{N}$ (Table 2). Compared with regular urea, OMU mitigated $\mathrm{N}$ loss due to a $\mathrm{NH}_{3}$ volatilization of 74.1 and $67.2 \%$ in the two study years. Since the industrial process of urea coating is not available for this product, perhaps a mixture of sulfur, wax, and a conditioner was used to give it a degree of hydrophobicity associated with coating resistance (Hignett, 1985). The presence of such a barrier for urea dissolution explains the relative delay in $\mathrm{NH}_{3}$ volatilization in OMU and SU, when compared with regular urea in the present study. Sulfur may help to neutralize, to some extent, the alkalinization associated with the released urea because of its acidic reaction in the soil. However, despite the possibility of similar effects due to the presence of either a coating barrier or acidification by sulfur, the SU treatment was not as effective in controlling $\mathrm{NH}_{3}$ volatilization. The use of SU practically resulted in a $19 \%$ loss of the $\mathrm{N}$ applied as $\mathrm{NH}_{3}$, regardless of the year (Table 2), or in about twice the loss of $\mathrm{N}$ in the OMU treatment, although it had approximately twice the sulfur concentration. However, the use of SU mitigated $\mathrm{N}$ loss in $53 \%$, compared with regular urea, in 2015. Contrarily, the efficiency of this product was not confirmed in 2016, when the volatilized $\mathrm{NH}_{3}-\mathrm{N}$ was $45 \%$ greater than that of the regular urea treatment.

The coating process and even the way the many components are mixed may result in fertilizers of contrasting efficiency, as reported by Rech et al. (2017). The accumulated $\mathrm{NH}_{3}-\mathrm{N}$ loss observed by these authors in the treatment with SU, also from the Nitro Gold commercial fertilizer, represented $23.2 \%$ of the $120 \mathrm{~kg} \mathrm{ha}^{-1} \mathrm{~N}$ fertilization rate used, while the $\mathrm{N}$ loss for urea was equivalent to $26.8 \%$. In their study, the presence of boron in the urea-based fertilizers also resulted in significant reductions in $\mathrm{NH}_{3}$ volatilization, since it deactivates the urease enzyme; although the efficiency of this process is not always high, it was better than that of a SU-type fertilizer (Mariano et al., 2019). However, Cancellier et al. (2016) observed that SU-type fertilizers resulted in lower $\mathrm{NH}_{3}$ losses than urea-based fertilizers with boron addition, making it challenging to reach a consensus on the topic.

Regardless of year-to-year differences, AS had the lowest $\mathrm{N}$ losses as $\mathrm{NH}_{3}$, with a Frac $\mathrm{GASF}_{\text {GS }}$ close to zero, while the urea-based fertilizers induced higher $\mathrm{NH}_{3}-\mathrm{N}$ losses. Regular urea and SU presented a Frac $\mathrm{GASF}_{\mathrm{G}}$ in the range of 0.13 to $0.40 \mathrm{~kg} \mathrm{NH}_{3}-\mathrm{N}$ per kilogram of $\mathrm{N}$ applied, while OMU was the most efficient $\mathrm{N}$ source, with a Frac $_{\mathrm{GASF}}$ of 0.04 to $0.10 \mathrm{~kg} \mathrm{NH}_{3}-\mathrm{N}$ per kilogram of $\mathrm{N}$ applied (Table 2). As a global average of all $\mathrm{N}$ sources, the Intergovernmental Panel on Climate Change (IPCC) (Eggleston et al., 2006) adopted a Frac $_{\text {GASF }}$ of $0.10 \mathrm{~kg} \mathrm{NH}_{3}-\mathrm{N}$ per kilogram of $\mathrm{N}$ applied for the estimates of volatilized $\mathrm{N}$ for greenhouse gas inventories, which is in a reasonable agreement with the averages of the $\mathrm{N}$ sources evaluated in the present study, especially in 2016, even though disaggregating urea from other fertilizers would improve the precision of estimates.

Corn yield presented a contrasting response to fertilizer type only in 2015 (Figure 3). The fertilization with AS resulted in a grain yield of 6.5 $\mathrm{Mg} \mathrm{ha}^{-1}$, while the non-fertilized control exhibited 
a yield of $2.2 \mathrm{Mg} \mathrm{ha}{ }^{-1}$. The use of urea-based fertilizers caused similar responses in yield, which was 5.1 $\mathrm{Mg} \mathrm{ha}^{-1}$ on average. In September 2015, the low precipitation during ear filling (Figure 1) reduced significantly the yield potential of corn. The highest net yield (above that of the control) in AS is in agreement with the lowest $\mathrm{N}$ loss as volatilized $\mathrm{NH}_{3}$, and a lower net yield for regular urea with the highest $\mathrm{NH}_{3}-\mathrm{N}$ loss contributes for a relationship between both variables. Despite the great differences between the amount of $\mathrm{N}$ volatilized between urea, $\mathrm{SU}$, and $\mathrm{OMU}$, a corresponding variation was not observed in corn grain yield. Although the total $\mathrm{N}$ accumulated by the plant was not assessed, the index leaf was used to evaluate the nutritional status of the plants. For AS, SU, OMU, urea, and the control, the respective $\mathrm{N}$ contents (\%) in the leaf index were $3.83( \pm 0.25), 3.51( \pm 0.16), 3.37( \pm 0.03), 3.36( \pm 0.11)$, and $2.16( \pm 0.08)$. Rambo et al. (2011) showed that the total $\mathrm{N}$ accumulated by the plant and index leaf at the earing stage was a very good predictor of corn yield, indicating their interrelation. However, the net $\mathrm{N}$ volatilization as $\mathrm{NH}_{3}$ only presented a trend

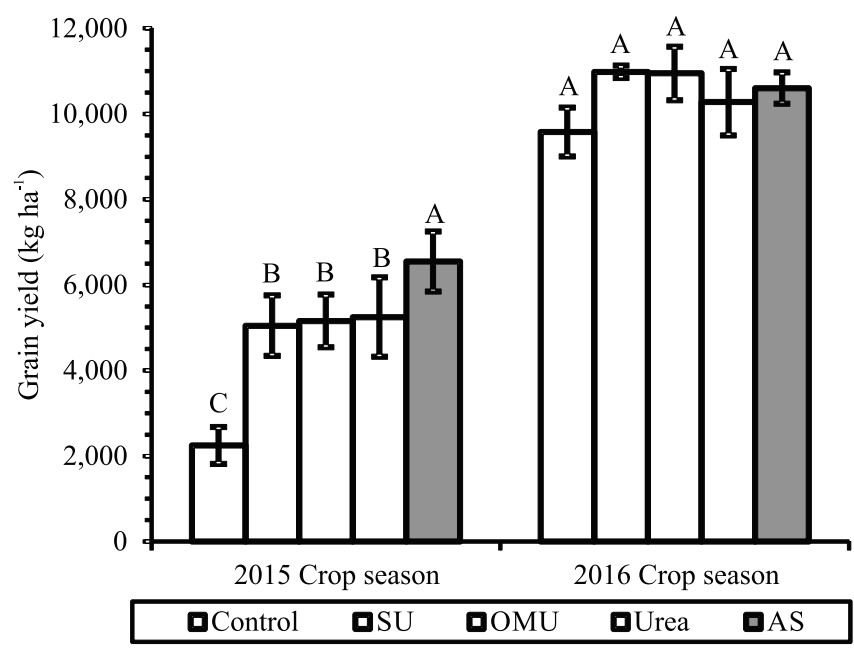

Figure 3. Grain yield of corn (Zea mays) fertilized with 150 $\mathrm{kg} \mathrm{ha}^{-1} \mathrm{~N}$ on soil surface in the 2015 and 2016 crop seasons. Means followed by equal letters do not differ by Fisher's least significant difference test, at 5\% probability. Bars indicate standard deviation. The coefficients of variation were 13.10 and $8.14 \%$ in 2015 and 2016, respectively. Control, without $\mathrm{N}$ fertilization; SU, sulfur-coated urea; OMU, organo-mineral-coated urea; Urea, regular urea; and AS, ammonium sulfate. of indirect relationship with the variation in the percentual increment in the $\mathrm{N}$ of the index leaf, taking the control as a reference (Figure 4). In 2016, average corn yield for all treatments was $10.5 \mathrm{Mg} \mathrm{ha}^{-1}$, as it did not respond to $\mathrm{N}$ fertilization. In this year, yields were about $100 \%$ higher than the highest yield of 2015, even though rainfall volume was smaller (Figure 1), but possibly more evenly distributed.

Cantarella et al. (2018) reviewed several studies and verified that $\mathrm{NH}_{3}$ volatilization rates are rarely accompanied by crop yields. The best explanation seems to be the use of $\mathrm{N}$ rates above the crop needs, which are the result of high soil fertility, cropping system, or other limitations related to nutrition, pests, and climate. Therefore, the better performance of AS in 2015 could be related to the provided $165 \mathrm{~kg} \mathrm{ha}^{-1}$ $\mathrm{S}$; however, the SU fertilizer with $16 \% \mathrm{~S}$, which added $65 \mathrm{~kg} \mathrm{ha}^{-1} \mathrm{~S}$, was ineffective in incrementing corn yield, when compared with regular urea or with OMU, which added $47 \mathrm{~kg} \mathrm{ha}^{-1} \mathrm{~S}$. In 2016, no effect of $\mathrm{S}$ fertilization was observed on yield performance. A review on crop yield response to $\mathrm{S}$ fertilizer in Brazil pointed out that no more than $\sim 26 \mathrm{~kg} \mathrm{ha}^{-1} \mathrm{~S}$ would be enough to meet plant demand and replenish soil reserves (Pias et al., 2019).

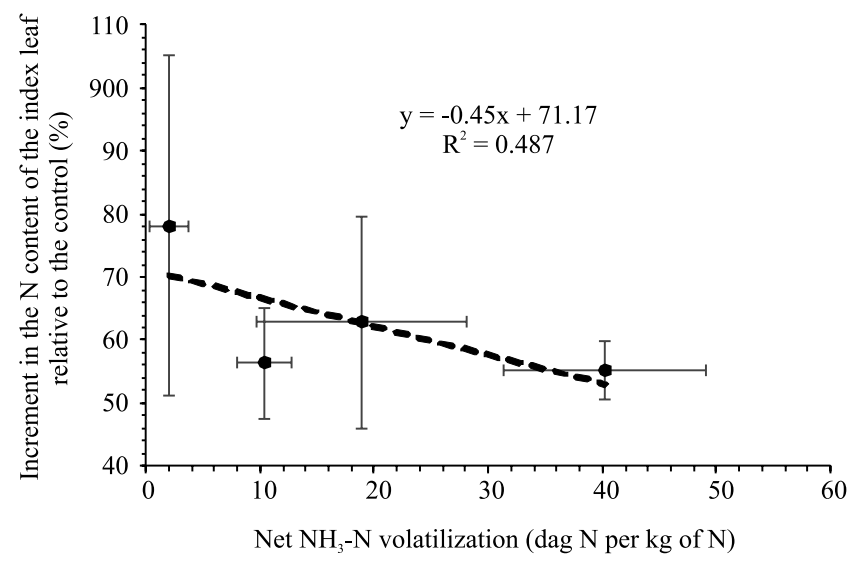

Figure 4. Regression of the increment in the nitrogen content of the corn (Zea mays) index leaf as a response to the net $\mathrm{NH}_{3}-\mathrm{N}$ volatilization in 2015 . $\mathrm{NH}_{3}-\mathrm{N}$ volatilization was considered the volatilized $\mathrm{N}$ of the $\mathrm{N}$ sources subtracted from that of the control, whereas the leaf index was estimated by the difference between the data from plants subjected to the treatments with $\mathrm{N}$ sources and to the control. Bars indicate the standard error of the mean. 


\section{Conclusions}

1. The organo-mineral-coated urea is the best ureabased fertilizer for reducing $\mathrm{NH}_{3}$ volatilization losses, although compromising corn (Zea mays) yield, while ammonium sulfate is the alternative for increasing yield and eliminating $\mathrm{NH}_{3}$ losses.

2. For the semiarid region of the state of Sergipe, Brazil, the amount of nitrogen lost by $\mathrm{NH}_{3}$ volatilization has no significant effect on corn yield and $\mathrm{N}$ nutrition.

\section{Acknowledgments}

To all field workers and technicians of Embrapa Tabuleiros Costeiros, for maintaining the experiments; to Petróleo Brasileiro S.A. (Petrobras), for financial support; toEmpresaBrasileiradePesquisaAgropecuária (Embrapa), for technical and scientific infrastructure; to Coordenação de Aperfeiçoamento de Pessoal de Nível Superior (Capes), for scholar fellowship; and to Conselho Nacional de Desenvolvimento Científico e Tecnológico ( $\mathrm{CNPq}$ ) and to Fundação de Amparo à Pesquisa do Estado do Rio de Janeiro (Faperj), for scientific fellowships.

\section{References}

ALVES, B.J.R.; URQUIAGA, S.; JANTALIA, C.P.; BODDEY, R.M. Influência de fungos e bactérias na eficiência da fertilização nitrogenada e na emissão de $\mathrm{N}_{2} \mathrm{O}$ para a atmosfera. In: MOREIRA, F.M. de S.; KASUYA, M.C.M. (Ed.). Fertilidade e biologia do solo: integração e tecnologia para todos. Viçosa: Sociedade Brasileira de Ciência do Solo, 2016. v.1, p.197-226.

ARAÚJO, E. da S.; MARSOLA, T.; MIYAZAWA, M.; SOARES, L.H. de B.; URQUIAGA, S.; BODDEY, R.M.; ALVES, B.J.R. Calibração de câmara semiaberta estática para quantificação de amônia volatilizada do solo. Pesquisa Agropecuária Brasileira, v.44, p.769-776, 2009. DOI: https://doi.org/10.1590/S0100204X2009000700018.

BLACK, A.S.; SHERLOCK, R.R.; SMITH, N.P. Effect of timing of simulated rainfall on ammonia volatilization from urea, applied to soil of varying moisture content. European Journal of Soil Science, v.38, p.679-687, 1987. DOI: https://doi.org/10.1111/j.1365-2389.1987.tb02165.x.

CANCELLIER, E.L.; SILVA, D.R.G.; FAQUIN, V.; GONÇALVES, B. de A.; CANCELLIER, L.L.; SPEHAR, C.R. Ammonia volatilization from enhanced-efficiency urea on no-till maize in brazilian cerrado with improved soil fertility. Ciência e Agrotecnologia, v.40, p.133-144, 2016. DOI: https://doi.org/10.1590/1413-70542016402031115.

CANTARELLA, H.; MONTEZANO, Z.F. Nitrogênio e enxofre. In: PROCHNOW, L.I.; CASARIN, V.; STIPP, S.R. (Ed.). Boas práticas para o uso eficiente de fertilizantes: nutrientes. Piracicaba: IPNI, 2010. v.2, p.5-46.

CANTARELlA, H.; OTTO, R.; SOARES, J.R.; SILVA, A.G. de B. Agronomic efficiency of NBPT as a urease inhibitor: a review. Journal of Advanced Research, v.13, p.19-27, 2018. DOI: https://doi.org/10.1016/j.jare.2018.05.008.

CANTARELLA, H.; TRIVELIN, P.C.O.; CONTIM, T.L.M.; DIAS, F.L.F.; ROSSETO, R.; MARCELINO, R.; COIMBRA, R.B.; QUAGGIO J.A. Ammonia volatilisation from urease inhibitor-treated urea applied to sugarcane trash blankets. Scientia Agricola, v.65, p.397-401, 2008. DOI: https://doi.org/10.1590/ S0103-90162008000400011.

CHIEN, S.H.; GEARHART, M.M.; VILLAGARCÍA, S. Comparison of ammonium sulfate with other nitrogen and sulfur fertilizers in increasing crop production and minimizing environmental impact: a review. Soil Science, v.176, p.327-335, 2011. DOI: https://doi.org/10.1097/SS.0b013e31821f0816.

COELHO, A.M.; FRANÇA, G.E. DE; PITTA, G.V.E.; ALVES, V.M.C.; HERNANI, L.C. Fertilidade de solos: nutrição e adubação do milho. In: CRUZ, J.C. (Ed.). Cultivo do milho. 4.ed. Sete Lagoas: Embrapa Milho e Sorgo, 2008. (Embrapa Milho e Sorgo. Sistemas de produção, 2). Available at: <https://ainfo.cnptia. embrapa.br/digital/bitstream/item/35316/1/Nutricao-adubacao. pdf $>$. Accessed on: Apr. 102020.

DA ROS, C.O.; AITA, C.; GIACOMINI, S.J. Volatilização de amônia com aplicação de uréia na superfície do solo, no sistema plantio direto. Ciência Rural, v.35, p.799-805, 2005. DOI: https://doi.org/10.1590/S0103-84782005000400008.

EGGLESTON, S.; BUENDIA, L.; MIWA, K.; NGARA, T.; TANABE, K. (Ed.). 2006 IPCC guidelines for national greenhouse gas inventories: agriculture, forestry and other land use. Hayama: IGES, 2006. v.4. Available at: <http://www.ipccnggip.iges.or.jp/public/2006gl/vol4.html>. Accessed on: Mar. 17 2020.

FAO. Food and Agriculture Organization of the United Nations. World reference base for soil resources 2014: international soil classification system for naming soils and creating legends for soil maps: update 2015. Rome, 2015. (FAO. World Soil Resources Report, 106). Available at: <http://refhub.elsevier.com/S01678809(17)30264-5/sbref0080>. Accessed on: May 222018.

FERREIRA, D.F. Sisvar: a computer statistical analysis system. Ciência e Agrotecnologia, v.35, p.1039-1042, 2011. DOI: https://doi.org/10.1590/S1413-70542011000600001.

HEFFER, P.; PRUD'HOMME, M. Global nitrogen fertiliser demand and supply: trend, current level and outlook. In: INTERNATIONAL NITROGEN INITIATIVE CONFERENCE, 7., 2016, Melbourne. Solutions to improve nitrogen use efficiency for the world: proceedings. Nairobi: The International Nitrogen Initiative, 2016. Available at: <http:/www.ini2016.com/ conference-proceedings-2>. Accessed on: Feb. 152020.

HIGNETT, T.P. Controlled-release fertilizers. In: HIGNETT, T.P. (Ed.). Fertilizer manual. Dordrecht: Martinus Nijhoff \& W. Junk Publishers, 1985. p.278-283. 
IFA. International Fertilizer Association. IFADATA. Available at: <http://ifadata.fertilizer.org/ucSearch.aspx>. Accessed on: Apr. 102020.

JANTALIA, C.P.; HALVORSON, A.D.; FOLLETT, R.F.; ALVES, B.J.R.; POLIDORO, J.C.; URQUIAGA, S. Nitrogen source effects on ammonia volatilization as measured with semistatic chambers. Agronomy Journal, v.104, p.1595-1603, 2012. DOI: https://doi.org/10.2134/agronj2012.0210.

LARA CABEZAS, W.A.R.; TRIVELIN, P.C.O.; KONDÖRFER, G.H.; PEREIRA, S. Balanço da adubação nitrogenada sólida e fluida de cobertura na cultura do milho, em sistema plantio direto no Triângulo Mineiro (MG). Revista Brasileira de Ciência do Solo, v.24, p.363-376, 2000. DOI: https://doi.org/10.1590/S010006832000000200014 .

MARIANO, E.; SANT ANA FILHO, C.R. de; BORTOLETTOSANTOS, R.; BENDASSOLI, J.A.; TRIVELIN, P.C.O. Ammonia losses following surface application of enhanced-efficiency nitrogen fertilizers and urea. Atmospheric Environment, v.203, p.242-251, 2019. DOI: https://doi.org/10.1016/j. atmosenv.2019.02.003.

PIAS, O.H. de C.; TIECHER, T.; CHERUBIN, M.R.; MAZURANA, M.; BAYER, C. Crop yield responses to sulfur fertilization in Brazilian no-till soils: a systematic review. Revista Brasileira de Ciência do Solo, v.43, p.1-21, 2019. DOI: https://doi.org/10.1590/18069657rbcs20180078.

RAMBO, L.; SILVA, P.R.F. da; STRIEDER, M.L.; SILVA, A.A. da; SANGOI, L.; VIEIRA, V.M. Índices nutricionais de $\mathrm{N}$ e produtividade de milho em diferentes níveis de manejo e de adubação nitrogenada. Pesquisa Agropecuária Brasileira, v.46, p.390-397, 2011. DOI: https://doi.org/10.1590/S0100204X2011000400008.
RECH, I.; POLIDORO, J.C.; PAVINATO, P.S. Additives incorporated into urea to reduce nitrogen losses after application to the soil. Pesquisa Agropecuária Brasileira, v.52, p.194-204, 2017. DOI: https://doi.org/10.1590/S0100-204X2017000300007.

SANGOI, L.; ERNANI, P.R.F.; SILVA, P.R.F. da. Maize response to nitrogen fertilization timing in two tillage systems in a soil with high organic matter content. Revista Brasileira de Ciência do Solo, v.31, p.507-517, 2007. DOI: https://doi.org/10.1590/S010006832007000300011 .

SANTOS, H.G. dos; JACOMINE, P.K.T.; ANJOS, L.H.C. dos; OLIVEIRA, V.A. de; LUMBRERAS, J.F.; COELHO, M.R.; ALMEIDA, J.A. de; CUNHA, T.J.F.; OLIVEIRA, J.B. de. Sistema brasileiro de classificação de solos. 3.ed. rev. e ampl. Brasília: Embrapa, 2013. 353p.

SILVA, F.C. (Org.). Manual de análises químicas de solos, plantas e fertilizantes. Brasília: Embrapa Comunicação para Transferência de Tecnologia; Rio de Janeiro: Embrapa Solos; Campinas: Embrapa Informática Agropecuária, 1999. 370p.

SOBRAL, L.F.; VIÉGAS, P.R.A.; SIQUEIRA, O.J.W. de; ANJOS, J.L. dos; BARRETO, M.C. de V.; GOMES, J.B.V. de. Recomendações para o uso de corretivos e fertilizantes no Estado de Sergipe. Aracaju: Embrapa Tabuleiros Costeiros, 2007. 251p.

SOMMER, S.G.; SHJOERRING, J.K.; DENMEAD, O.T. Ammonia emission from mineral fertilizers and fertilized crops. Advances in Agronomy, v.82, p.557-622, 2004. DOI: https://doi.org/10.1016/S0065-2113(03)82008-4.

ZHAO, W.; CAI, Z.-C.; XU, Z.-H. Does ammonium-based $\mathrm{N}$ addition influence nitrification and acidification in humid subtropical soils of China? Plant and Soil, v.297, p.213-221, 2007. DOI: https://doi.org/10.1007/s11104-007-9334-1. 